\title{
DUCTILE INTERMETALLIC TOUGHENED CARBIDE MATRIX COMPOSITES
}

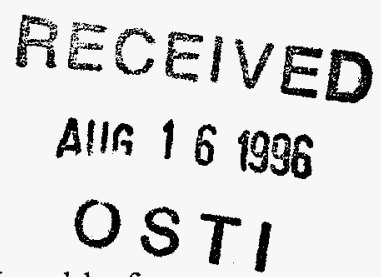

K. P. Plucknett, T. N. Tiegs, P. F. Becher, S. B. Waters and P. A. Menchhofer

Metals and Ceramics Div., Oak Ridge National Laboratory, Oak Ridge, TN 37830

Ductile nickel aluminide $\left(\mathrm{Ni}_{3} \mathrm{Al}\right)$ alloys have been used as a 'binder' phase for the fabrication of both titanium and tungsten carbide ( $\mathrm{TiC}$ and $\mathrm{WC}$ ) matrix composites. $\mathrm{Ni}_{3} \mathrm{Al}$ alloys exhibit good resistance to aqueous acidic corrosion environments. These alloys are also unusual in that their yield strength increases with temperature, to a maximum at $700-800^{\circ} \mathrm{C}$. These properties, combined with high tensile ductilities (up to $50 \%$ strain), make $\mathrm{Ni}_{3} \mathrm{Al}$ a potentially attractive replacement for $\mathrm{Co}$ in cemented carbide fabrication. Materials have been fabricated by both hot-pressing and vacuum-sintering, with $\mathrm{Ni}_{3} \mathrm{Al}$ contents ranging from 15 to 95 vol. \%. Vacuum-sintering cycles were generally similar to those used for the fabrication of $\mathrm{WC} / \mathrm{Co}$ and $\mathrm{TiC} / \mathrm{Ni}$ (i.e. $T_{\text {sint }} \sim 1450-1600^{\circ} \mathrm{C}$ ), resulting in sintered densities $>95 \%$ of theoretical. WC/Ni3Al materials exhibited an order of magnitude improvement in corrosion resistance over $\mathrm{WC} / \mathrm{Co}$, during immersion tests in either sulfuric or nitric acid. These materials also demonstrated improved high temperature strength retention compared to $\mathrm{WC} / \mathrm{Co}$ cermets, though the initial room temperature strengths were lower. Fracture toughness varied between 8 and $25 \mathrm{MPa} \cdot \mathrm{m}^{1 / 2}$, and depended primarily upon $\mathrm{Ni}_{3} \mathrm{Al}$ content and composition.

\section{INTRODUCTION}

Cemented carbides, such as tungsten carbide/cobalt (WC/Co), exhibit a unique combination of properties that have led to their implementation in a large number of industrial applications, including; cutting tools, drilling bits, wire drawing dies, punch/die sets, spray and blast nozzles, aluminum/plastic extrusion dies etc. [1]. A summary of some of the mechanical properties of WC/Co cemented carbides is shown in Table I (from data collated by Ettmayer [2]). The fracture behavior of these materials is not fully understood, however, a number of recent studies have sought to gain further understanding of the fracture mechanisms involved [3-7].

There are several reasons for exploring alternative binders to Co, notably that Co is a rare, strategic material (and hence relatively expensive) and that it exhibits poor resistance to corrosion in aqueous and acidic environments. Several replacement binder systems have been investigated. These include $\mathrm{Fe}$ and/or Ni with small Co additions $[8,9]$, which gave properties comparable to Co alone, and also ferro-alloys (i.e. stainless steel or $\mathrm{Fe}-\mathrm{Co}-\mathrm{NiMoB}$ ) $[10,11]$. A mixed $\mathrm{Ni}-\mathrm{Al}$ binder system was investigated by Viswanadham et al [12],with the aim of 'hardening' the binder phase by precipitation of the ordered $\gamma^{\prime} \mathrm{Ni}_{3} \mathrm{Al}$ intermetallic phase. In 


\section{DISCLAIMER}

This report was prepared as an account of work sponsored by an agency of the United States Government. Neither the United States Government nor any agency thereof, nor any of their employees, makes any warranty, express or implied, or assumes any legal liability or responsibility for the accuracy, completeness, or usefulness of any information, apparatus, product, or process disclosed, or represents that its use would not infringe privately owned rights. Reference herein to any specific commercial product, process, or service by trade name, trademark, manufacturer, or otherwise does not necessarily constitute or imply its endorsement, recommendation, or favoring by the United States Government or any agency thereof. The views and opinions of authors expressed herein do not necessarily state or reflect those of the United States Government or any agency thereof. 


\section{DISCLAIMER}

Portions of this document may be illegible in electronic image products. Images are produced from the best available original document. 
the present study a range of cemented carbides have been investigated, which utilize ductile $\mathrm{Ni}_{3} \mathrm{Al}$ binders as a replacement for $\mathrm{Co}$ [13-15]. $\mathrm{Ni}_{3} \mathrm{Al}$ binders have been selected due to their improved corrosion resistance and high temperature strength retention relative to Co.

Table I. Mechanical properties of WC/Co cemented carbides for three different Co contents (summarized from data presented in ref. 2).

\begin{tabular}{llll}
\hline \hline Co content, wt. \% (vol. \%) & $5(8.5)$ & $15(23.7)$ & $25(37)$ \\
\hline Vickers hardness & $1400-1800$ & $1100-1450$ & $700-1100$ \\
Comp. strength (MPa) & $5600-6100$ & $4300-4900$ & $3200-3700$ \\
Trans. rupture strength $(\mathrm{MPa})$ & $1800-2800$ & $2600-3200$ & $2900-3300$ \\
Fracture toughness $\left(\mathrm{MPa} . \mathrm{m}^{1 / 2}\right)$ & $8-10$ & $15-17.5$ & $18-22$ \\
\hline \hline
\end{tabular}

\section{EXPERIMENTAL TECHNIQUES}

Powder mixtures were prepared either by ball milling or attritor milling in nonaqueous medium (iso-propanol or hexane). Hot-pressing was performed in graphite dies, at various temperatures between 1150 and $1450^{\circ} \mathrm{C}$, with uniaxial pressures of up to $34 \mathrm{MPa}$. Vacuum-sintering was performed in a conventional gas-pressure sintering furnace at temperatures from 1400 to $1600^{\circ} \mathrm{C}$, for up to two hours at temperature. Some samples were also given a second stage low-pressure hot-isostatic pressing (LPHIP) treatment, with an applied argon gas pressure of 2 $\mathrm{MPa}$. The densities of both hot-pressed and vacuum sintered were determined by immersion in distilled water. The microstructures of dense materials were assessed by optical and scanning electron microscopy. Fracture toughness has been measured using a number of different techniques, namely; indentation [16], indentation/strength [17] and applied moment double cantilever beam (AMDCB) [18]. Fracture strength was measured in four point bend, using inner/outer spans of either $20 / 40 \mathrm{~mm}$ or $6.35 / 19.05 \mathrm{~mm}$. Vickers hardness was obtained using loads from 10 to $50 \mathrm{~kg}$. The corrosion resistance of selected materials was determined by immersion in $10 \%$ acid solutions for a period of 48 hours.

\section{RESULTS AND DISCUSSION}

\section{(A) Hot-pressed cemented carbides}

Theoretically dense $\mathrm{WC} / \mathrm{Ni}_{3} \mathrm{Al}$ cemented carbides are prepared by hot-pressing at temperatures of $\sim 1350^{\circ} \mathrm{C}$. Higher temperatures result in exudation of molten $\mathrm{Ni}_{3} \mathrm{Al}$ from the sample and graphite die. Some mechanical properties of the hotpressed cemented carbides are shown in Table II. Data for WC/Co is shown for 
comparison. The properties of the $\mathrm{Ni}_{3} \mathrm{Al}$ bonded $\mathrm{WC}$ composites are generally similar to $\mathrm{WC} / \mathrm{Co}$, although the room temperature strengths are slightly lower. However, it is apparent that the $\mathrm{Ni}_{3} \mathrm{Al}$ bonded materials retain a much higher proportion of their RT strength at elevated temperatures.

Table II. Summary of some of the mechanical properties of hot-pressed $\mathrm{Ni}_{3} \mathrm{Al}$ bonded WC and TiC matrix composites.

\begin{tabular}{|c|c|c|c|c|}
\hline \multirow{2}{*}{$\begin{array}{l}\text { Composition } \\
\text { (Vol. \%) }\end{array}$} & \multirow{2}{*}{$\begin{array}{l}\text { Hardness } \\
\text { (GPa) }\end{array}$} & \multicolumn{2}{|c|}{ Flexure strength (MPa) } & \multirow{2}{*}{$\begin{array}{l}\text { Fracture Toughness } \\
\left(\mathrm{MPam}^{1 / 2}\right)\end{array}$} \\
\hline & & RT & $800^{\circ} \mathrm{C}$ & \\
\hline $\mathrm{WC} / 17 \mathrm{Ni}_{3} \mathrm{Al}$ & $14-18$ & $1200-1350$ & 1395 & $10-20$ \\
\hline $\mathrm{WC} / 68 \mathrm{Ni}_{3} \mathrm{Al}$ & 7 & 1750 & 1640 & 25 \\
\hline $\mathrm{TiC} / 17 \mathrm{Ni}_{3} \mathrm{Al}$ & $16-20$ & $750-900$ & 745 & $8-14$ \\
\hline $\mathrm{WC} / 17 \mathrm{Co}$ & $12-14$ & -2000 & N/A & $17-18$ \\
\hline
\end{tabular}

The corrosion resistance of WC/Ni3 $\mathrm{Al}$ composites in three different acid solutions is shown in Fig. 1. A considerable improvement in resistance to corrosion in both nitric and sulfuric acid can be obtained via substitution of $\mathrm{Ni}_{3} \mathrm{Al}$ for $\mathrm{Co}$. This effect is further emphasized when noting the lower binder content of the two WC/Co materials, compared to the WC/Ni3Al cermet. There is no significant difference in the corrosion behavior of $\mathrm{Ni}_{3} \mathrm{Al}$ or $\mathrm{Co}$ binders in hydrochloric acid.

\section{(B) Vacuum-sintered cemented carbides}

Recent work has focused upon the development of vacuum-sintering techniques, in order to be able to fabricate materials to near-net shape (to improve the industrial viability of these materials). Sintered densities greater than $99 \%$ of theoretical were achieved for the $\mathrm{TiC}$ cermets with the higher $\mathrm{Ni}_{3} \mathrm{Al}$ contents (i.e. $>25$ vol. \%). Densities greater than $95 \%$ of theoretical were obtained for all the examined $\mathrm{TiC}$ based compositions, when sintering at temperatures between 1500 and $1600^{\circ} \mathrm{C}$. Generally, WC based materials can also be vacuum sintered to high density, as shown in Table III. However, sintered densities are low for the fine $(\sim 0.8 \mu \mathrm{m})$ WC powder, presumably due to increased oxygen contamination.

Initial investigation of two-stage vacuum/low-pressure HIP (LPHIP) processing has produced mixed results, with the identification of an unusual de-sintering mechanism with the $\mathrm{TiC}$ based compositions, even for samples initially vacuum sintered to densities in excess of $99 \%$ of theoretical. Large 'binder-free' regions were apparent in the LPHIP processed sample. High magnification SEM imaging demonstrated that the carbide grains in this region were clean, with no residual binder evident. It was also apparent that the binder/ carbide contact angle was approaching $90^{\circ}$ at the edge of the 'binder-free' regions, significantly different from the contact angle of 'pure' $\mathrm{Ni}_{3} \mathrm{Al}$ on $\mathrm{TiC}$, which is $\sim 20^{\circ}$. During sintering the binder composition is modified via incorporation of $\mathrm{T} i$ and $\mathrm{C}$ (from dissolution of 
the $\mathrm{TiC}$ grains), and this appears to result in de-wetting. This effect is currently being assessed in more detail, in order to gain a better understanding of the dewetting mechanism (via controlled alteration of the binder composition). Dewetting was not observed in any of the WC/Ni3 $\mathrm{Al}$ based systems, with density increases noted for nearly every composition (Table III).

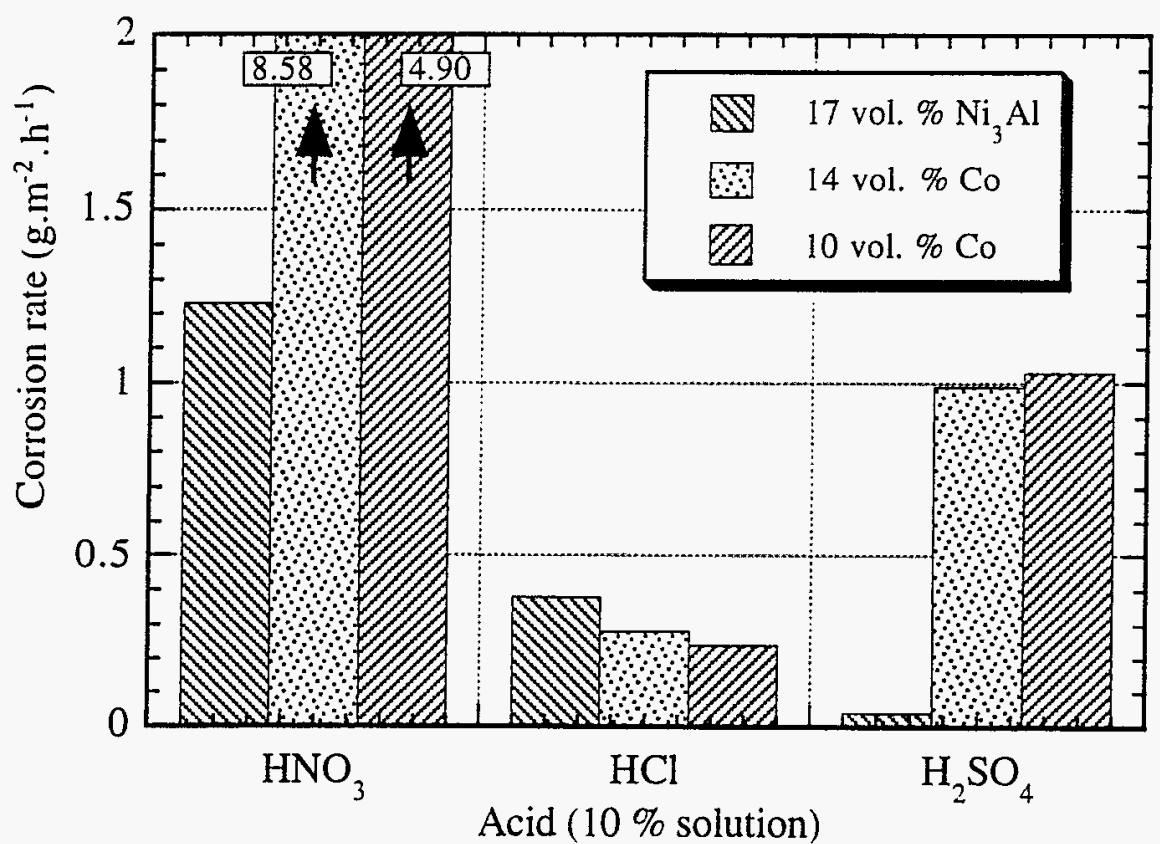

Figure 1. Corrosion rates, determined by weight loss, of a hot-pressed $\mathrm{WC} / \mathrm{Ni} 3 \mathrm{Al}$ cermet immersed in $10 \%$ (by volume) acid solutions for $48 \mathrm{~h}$ (at $25^{\circ} \mathrm{C}$ ). The WC/Co materials were commercial grade products.

Table III. Density values for vacuum sintered and low-pressure HIPed (1.7 MPa $\mathrm{Ar}$ ) WC/Ni3 $\mathrm{Al}$ based cermets (average particle size of fine WC powder $\sim 0.8 \mu \mathrm{m}$ ).

\begin{tabular}{lcccc}
\hline \hline Composition & \multicolumn{2}{c}{$\begin{array}{c}\text { Density after vacuum } \\
\text { sintering (\% T.D.) }\end{array}$} & \multicolumn{2}{c}{$\begin{array}{c}\text { Density after low } \\
\text { pressure HIP (\% T.D.) }\end{array}$} \\
\cline { 2 - 5 } & $1550^{\circ} \mathrm{C}$ & $1600^{\circ} \mathrm{C}$ & $1550^{\circ} \mathrm{C}$ & $1600^{\circ} \mathrm{C}$ \\
\hline WC-20 vol. \% Ni $3 \mathrm{Al}$ & 96.8 & 96.9 & 98.6 & 98.3 \\
WC-20 vol. \% Ni $3 \mathrm{Al}$ (5 \% Fe) & 96.0 & 98.3 & 98.9 & 99.5 \\
WC-20 vol. \% Ni $3 \mathrm{Al}$ (5 \% W) & 96.0 & 97.1 & 98.2 & 98.3 \\
WC-20 vol. \% $\mathrm{Ni}_{3} \mathrm{Al}$ (5 \% Ti) & 92.0 & 92.9 & 95.7 & 95.4 \\
WC (Fine)-20 vol. \% Ni $3 \mathrm{Al}$ & 84.3 & 85.6 & 83.7 & 85.7 \\
WC-30 vol. \% Ni3 Al & 98.4 & 97.9 & 98.7 & 98.1 \\
\hline \hline
\end{tabular}




\section{(C) Mechanical behavior of vacuum-sinter/LPHIP processed TiC/Ni 3 Al cermets.}

An initial mechanical property survey has been performed upon a series of vacuum-sinter/LPHIP processed $\mathrm{TiC} / \mathrm{Ni}_{3} \mathrm{Al}$ cermets. As previously noted, these materials contain regions of coarse porosity. However, it was felt that these materials would provide a property baseline for the assessment of future vacuumsintered materials. Flexure strength has been obtained in four-point loading, with typically 20 plus tests for each composition. The effects of $\mathrm{Ni}_{3} \mathrm{Al}$ content upon the room temperature flexure strength are shown in Fig. 2. High strengths are obtained, despite the retained porosity in these materials. Weibull moduli plots for cermets prepared with 15 and 40 vol. \% Ni3Al binder are shown in Fig. 3. Even though coarse porosity is present, the materials show reasonable reliability (damage tolerance), particularly at the higher binder content.

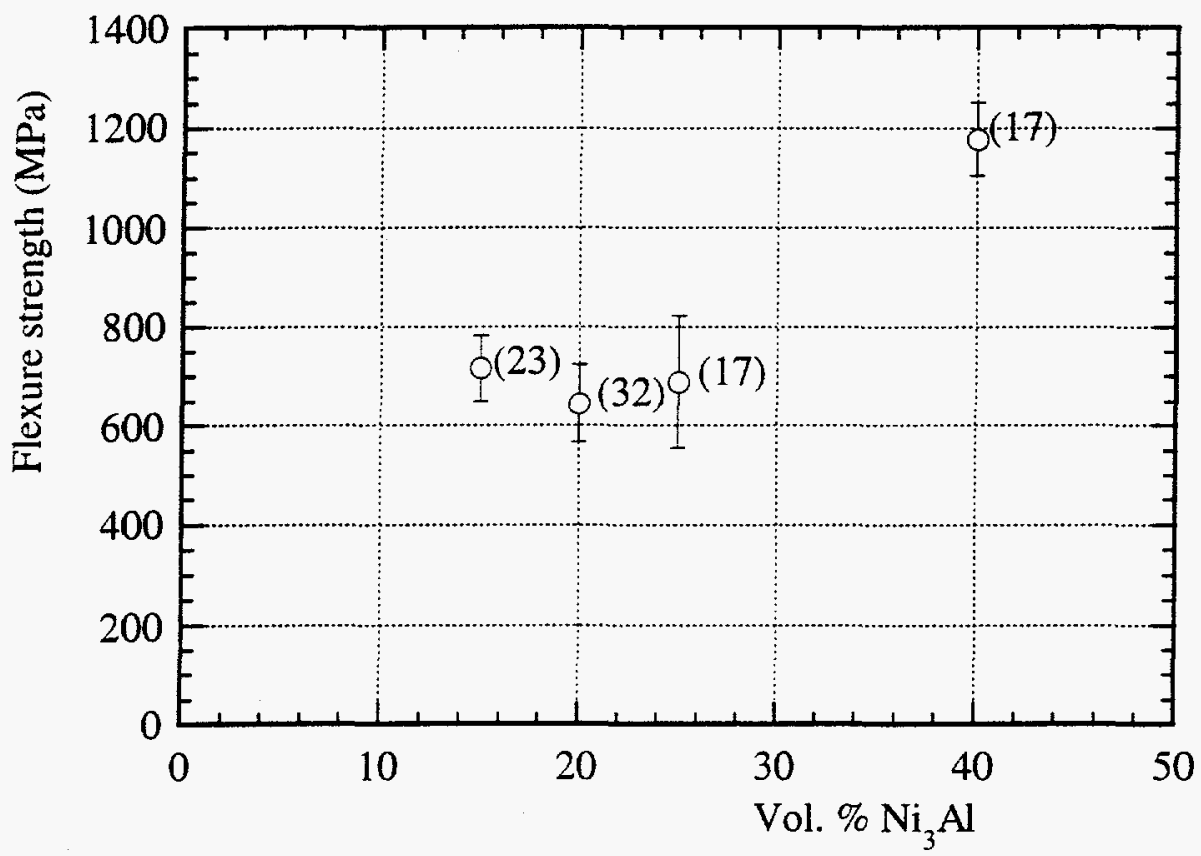

Figure 2. The effects of $\mathrm{Ni}_{3} \mathrm{Al}$ binder volume on the flexure strength of $\mathrm{TiC}$ based cermets (vacuum-sinter plus LPHIP processed samples). Number of tests indicated in parenthesis.

In addition to flexure testing, preliminary measurement of the ' $R$ ' curve behavior of these materials has been performed. Plateau fracture toughness values for cermets with 25 and 40 vol. \% binder were 9-10 and 11-12 MPa.m ${ }^{1 / 2}$ respectively. The ' $R$ ' curves for two specimens with 40 vol. \% binder, and retained coarse porosity, are shown in Fig. 4. A pronounced ' $R$ ' curve is apparent. Toughening mechanisms in these materials are currently being assessed further, with high density compositions. 


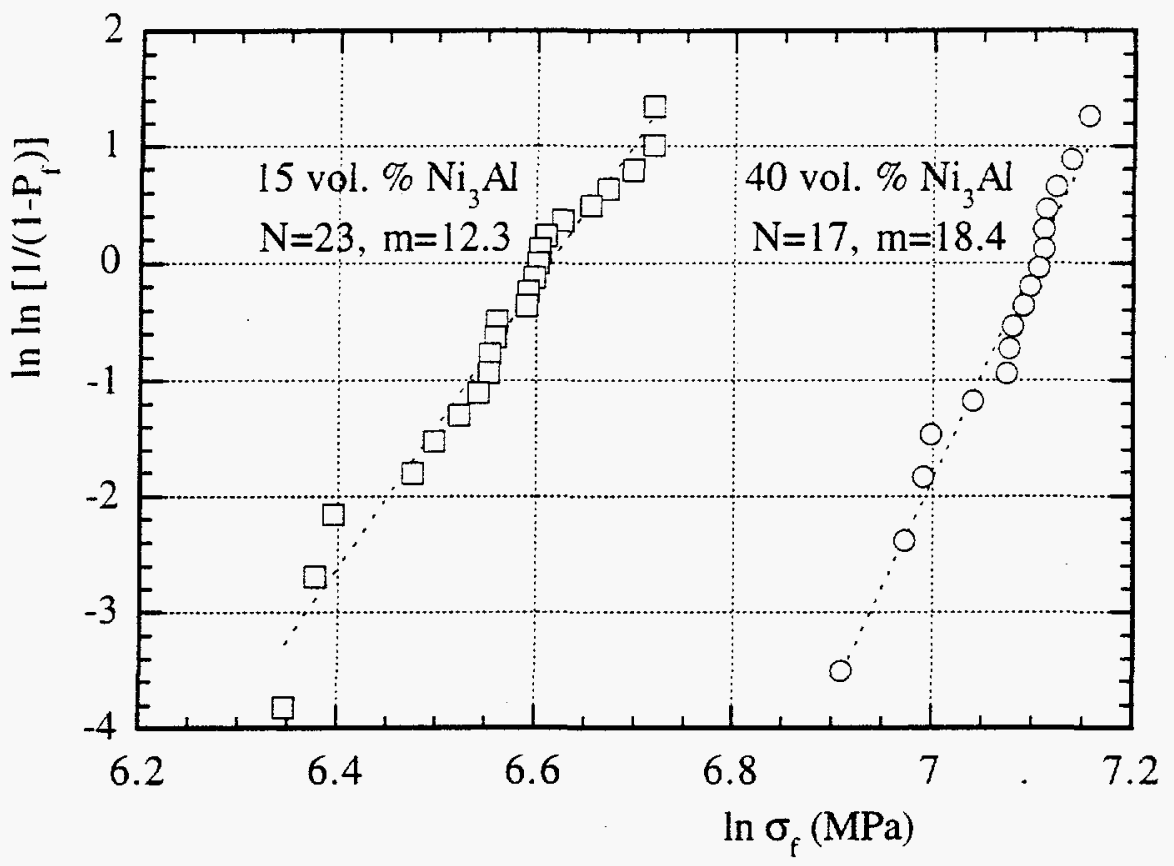

Figure 3. Weibull plots for vacuum-sintered/LPHIP processed $\mathrm{TiC} / \mathrm{Ni}_{3} \mathrm{Al}$ composites prepared with 15 and $40 \mathrm{vol}$. \% binder. Samples tested in four point bend.

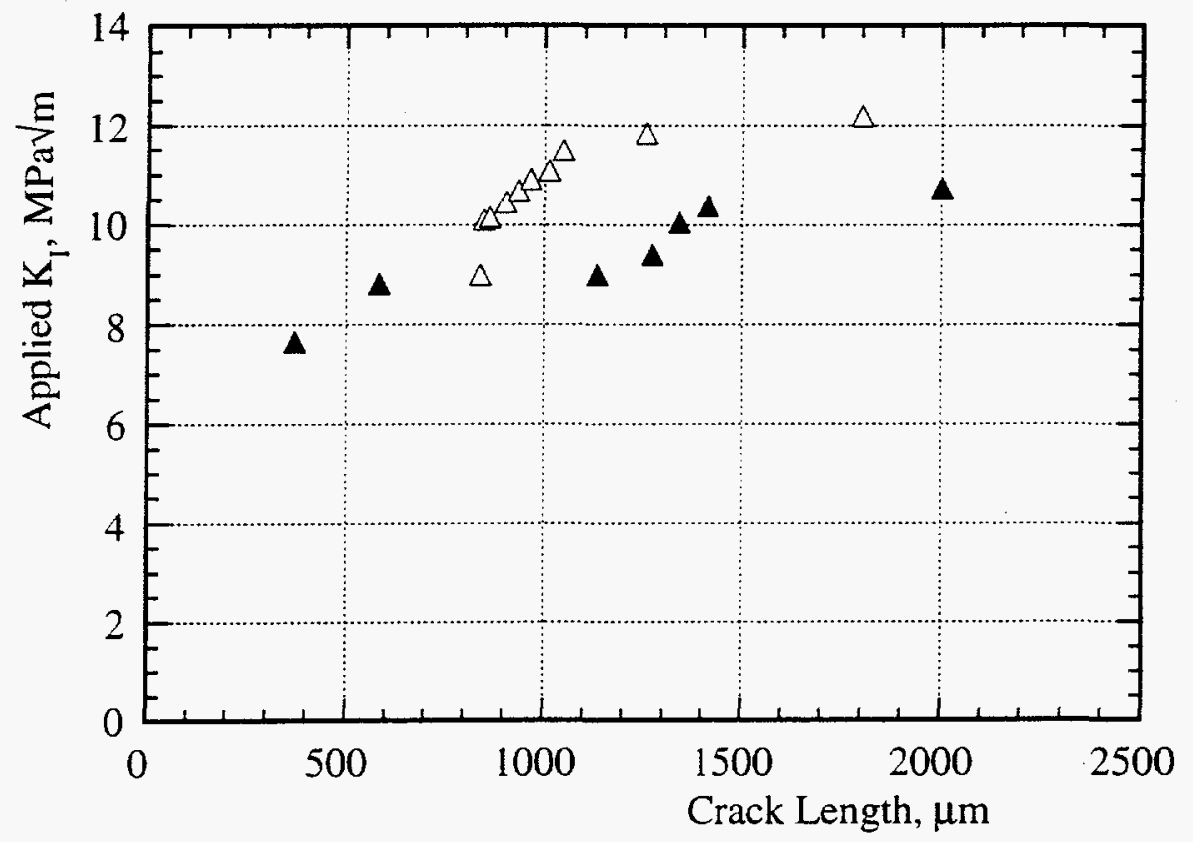

Figure 4. 'R' curves for two $\mathrm{TiC}$ based cermet samples prepared with $40 \mathrm{vol}$. \% $\mathrm{Ni}_{3} \mathrm{Al}$ binder. AMDCB sample geometry. 


\section{CONCLUSIONS}

A range of carbide based cermets have been developed, utilizing a ductile nickel aluminide binder phase. High density materials have been fabricated by both hotpressing and vacuum-sintering. The densities of vacuum-sintered materials (with 15 to 40 vol. \% nickel aluminide binder) ranged from $\sim 95 \%$ T.D., for the low binder content samples, to $>99 \%$ T.D. for the highest binder contents. An unusual de-wetting phenomenon was noted for $\mathrm{TiC} / \mathrm{Ni}_{3} \mathrm{Al}$ cermets when a postvacuum-sinter low-pressure HIP treatment was employed. The cause of this effect is currently being assessed.

The corrosion resistance of hot-pressed $\mathrm{WC} / \mathrm{Ni}_{3} \mathrm{Al}$ materials was found to be an order of magnitude better than that of comparable WC/Co hardmetals in both nitric and sulfuric acid environments.

Although an initial property assessment was performed with samples containing regions of coarse porosity, these materials have been found to exhibit a good combination of strength, reliability and fracture toughness. The fracture behavior of high density cermets is currently being assessed via the use of in-situ fracture studies within a scanning electron microscope, using an AMDCB specimen geometry. This work will be discussed in a future publication.

\section{ACKNOWLEDGMENTS}

The authors thank Drs. J. H. Schneibel and R. Subramanian for review of the manuscript. Research sponsored by the U.S. Department of Energy, Assistant Secretary for Energy Efficiency and Renewable Energy, Office of Industrial Technologies, Advanced Industrial Materials Program, under contract DE-AC05960R22464 with Lockheed Martin Energy Research Corp. KPP is also supported by an appointment to the ORNL Postdoctoral Research Program administered by the Oak Ridge Institute for Science and Technology.

\section{REFERENCES}

1. R.W. Stevenson, pp. 773-83 in ASM Handbook, Vol. 7, 1984.

2. P. Ettmayer, Ann. Rev. Mater. Sci., 19 145-64 (1989).

3. M. Nakamura and J. Gurland, Metall. Trans., 11A 141-46 (1980).

4. L.S. Sigl and H.E. Exner, Metall. Trans., 18A 1299-308 (1987).

5. L.S. Sigl and H.F. Fischmeister, Acta Metall., 36 [4] 887-97 (1988).

6. D.B. Marshall, W.L. Morris, B.N. Cox and M.S. Dadkhah, J. Am. Ceram. Soc., 73 [10] 2938-43 (1990).

7. K.S. Ravichandran, Acta Metall. Mater., 42 [1] 143-50 (1994).

8. H. Holleck, pp. 849-58 in Science of Hard Materials, R.K. Viswanadham, D.J. Rowcliffe and J. Gurland, Eds., Plenum Press, New York, NY, 1981.

9. L. Prakash, H. Holleck, F. Thümmler and G.E. Spriggs, pp. 118-21 in Towards Improved Performance of Tool Materials, R.S. Irani, E.A. 
F.A. Kirk, Eds., The Metals Society, London, 1982.

10. T. Farooq and T.J. Davies, pmi, 22 [4] 12-16 (1990).

11. T. Farooq and T.J. Davies, Int. J. Powder Metall., 27 [4] 347-355 1991.

12. R.K. Viswanadham, P.G. Lindquist and J.A. Peck, pp. 873-85 in Science

of Hard Materials, R.K. Viswanadham, D.J. Rowcliffe and J. Gurland, Eds., Plenum Press, New York, NY, USA, 1981.

13. T. N. Tiegs and R.R. MacDonald, US Patent \#4.919.718, April 1990.

14. T. N. Tiegs and R.R. MacDonald, US Patent \#5,015,280, May 1991.

15. K.P. Plucknett, T.N. Tiegs, K.B. Alexander, P.F. Becher, J.H. Schneibel, S.B. Waters and P.A. Menchhofer, pp. 511-520 in Proc. of the CIM Int. Symp. on Advanced Ceramics for Structural and Tribological Applications, Eds., T. Troczynski and H.M. Hawthorne, CIM, Vancouver, British Columbia, 1995.

16. G.R. Antis, P. Chantikul, B.R. Lawn and D.B. Marshall, J. Am. Ceram. Soc., 64 [9] 533-38 (1981).

17. P. Chantikul, G.R. Antis, B.R. Lawn and D.B. Marshall, J. Am. Ceram. Soc., 64 [9] 539-43 (1981).

18. S.W. Freiman, D.R. Mulville and P.W. Mast, J. Mater. Sci., 8 1527-33 (1973). 